\title{
THE PELAGIC PHASE IN THE LIFE HISTORY OF THE AMPHIPOD GENUS BATHYPOREIA
}

\author{
By E. Emrys Watkin, B.Sc., Ph.D. \\ From the Department of Zoology, University College of Wales, \\ Aberystwyth, and the Marine Biological Station, Millport \\ (Text-figs. I-2)

\begin{tabular}{llllll}
\multicolumn{3}{c}{ CONTENTS } & & & \\
Introduction \\
The Bathyporeia fauna of the sand of
\end{tabular}

\section{INTRODUCTION}

During the year $1936 \mathrm{Mr}$ Richard Elmhirst, Director of the Scottish Marine Biological Station at Millport, carried out a series of tow-nettings across the waters of Kames Bay at varying times after nightfall, mainly between the hours of Io p.m. and midnight, to ascertain the nature and extent of the faunal immigration into the bay from outside waters, and of the nocturnal and vertical movement of the fauna which normally lies buried in the sand during the day. The net employed was an ordinary coarse tow-net supplemented on occasions with a finer net; however, the latter net captured but few amphipods and its results will be neglected in the present paper. The method employed was to walk into the water at the edge of the incoming or outgoing tide to a depth of about $2 \mathrm{ft}$. and to walk across the bay following the edge of the tide trailing the net about Io ft. posteriorly and at arms' length into the tidal flow, thus avoiding as far as possible disturbances set up in the water by the walking movement. Each sample consisted of a tow of approximately I00 yards. Thus the position of each sample is determined by the time it was taken in relation to the day of the lunar month, and samples were obtained at all levels from high-water mark to low-water mark. I am indebted to Mr Elmhirst for the opportunity of examining the Bathyporeia taken in these samples and for his critical comments during this investigation. 


\section{The BATHyPoreia Fauna of the SAND of Kames BAY*}

An appreciation of the nocturnal vertical movement of these amphipods into the water of the tidal flow necessitates an analysis of their abundance in the intertidal sand. During the latter half of March I937 a series of three traverses were sampled from the high-water mark of spring tides to the lowwater mark of spring tides. Each traverse was sampled at intervals of approximately 5 yards. Each sample consisted of the fauna obtained by sieving the sand from a surface area of one square foot, to a depth of $I$ in., through a brass wire sieve of 30 meshes to the linear inch. Experience on Kames Bay and elsewhere had shown that these amphipods do not bury themselves deeply into the sand and that the total population, apart from the newly hatched forms, which can pass through the meshes of the sieve, may be captured by this means.

The first traverse was taken approximately along the centre line of the bay and the second and third respectively at a distance of 20 yards to the left and right of the first. The result of the analysis of the samples is given in Table I and is represented diagrammatically against the background of the bay in Fig. I.

Four species of the genus Bathyporeia occur in this area (Watkin, I938), $B$. pilosa Lindström, B. pelagica Bate, B. elegans Watkin, and B. guilliamsoniana Bate, and they show a definite zonation from high-tide mark to lowtide mark. The upper 30 yards of the 200 yard traverse show a complete absence of Bathyporeia. The next 45 yards is occupied by B. pilosa, which forms a definite belt across the bay sharply demarcated at its upper and lower limits, particularly the latter. The concentration of individuals in the centre of this belt is particularly heavy; as many as I205 individuals per square foot are recorded, with an average number per sample of almost 300 . The sharpness of the lower edge of the belt is particularly noteworthy; thus sample 12 in traverse three gave I205 individuals whilst 5 yards nearer low-water mark the number drops to 42 and the next sample records the lower limit of the belt. There follows an area of 35 yards, samples I6-22, barren of Bathyporeia, with $B$. pelagica appearing in sample 23 and forming a second well-defined belt across the bay 40 yards in width, disappearing in sample $3 I$. The concentration of $B$. pelagica is very considerably less than that of $B$. pilosa, averaging less than 20 per square foot. The third zone is formed by $B$. elegans which overlaps to some extent the $B$. pelagica zone and continues to the

* Kames Bay, Great Cumbrae, is a comparatively small bay bounded on the north-land side by the Marine Promenade of Millport and on the east and west side by sandstone rocks which wear down to a fine reddish sand unmixed with clay which forms the soil of the bay. On the south side the bay is open to the waters of the Firth of Clyde, the island of Little Cumbrae and the two promontories which form the southern points of the island of Great Cumbrae afford some protection. At low tide a stretch of sand roughly 280 yards from east to west and $\mathrm{r} 80$ yards from north to south is exposed. 
Table I. Number of Individuals of BAthyporeia Per Square Foot in TRAVERSES I, II AND III

Sample numbers in each traverse are at corresponding tide levels A, B. pilosa; B, B. pelagica; C, B. elegans; D, B. guilliamsoniana

Sample
no.
I-6
7
8
9
10
II
I2
13
14
15
$16-22$
23
24
25
26
27
28
29
30
31
32
33
34
35
36

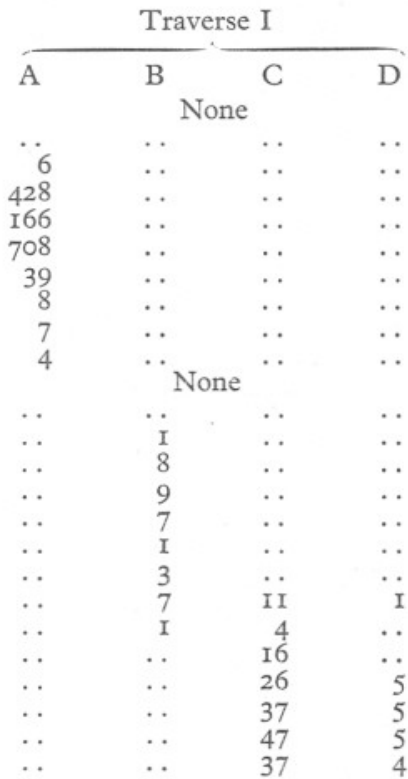

\section{Sample} no.

Traverse III

\begin{tabular}{|c|c|c|c|c|}
\hline & & & & \\
\hline no. & A & B & C & D \\
\hline I-6 & & None & & \\
\hline 7 & 95 & $\ldots$ & .. & $\ldots$ \\
\hline 8 & 357 & . & . & . \\
\hline 9 & 483 & $\cdots$ & .. & .. \\
\hline 10 & 860 & .. & .. & .. \\
\hline II & 788 & .. & .. & .. \\
\hline I2 & 1205 & .. & .. & . \\
\hline I3 & 42 & . & .. & .. \\
\hline $\mathrm{I} 4$ & . & .. & .. & .. \\
\hline $\begin{array}{c}15 \\
16-22\end{array}$ & .. & ${ }^{\prime}$ None & .. & . \\
\hline 23 & .. & 4 & .. & $\ldots$ \\
\hline 24 & .. & 6 & . & .. \\
\hline 25 & .. & I7 & 2 & .. \\
\hline 26 & .. & 47 & . & .. \\
\hline 27 & .. & 99 & 2 & . \\
\hline 28 & . & $\begin{array}{l}29 \\
2 I\end{array}$ & 6 & $\ddot{I}$ \\
\hline $\begin{array}{l}29 \\
30\end{array}$ & $\begin{array}{l}\ldots \\
.\end{array}$ & $\begin{array}{l}2 \text { I } \\
\text { IO }\end{array}$ & $\begin{array}{l}12 \\
21\end{array}$ & $\frac{1}{7}$ \\
\hline $3 \mathrm{I}$ & .. & I & I4 & .. \\
\hline 32 & .. & . & 22 & .. \\
\hline 33 & .. & . & 39 & 5 \\
\hline 34 & .. & . & 38 & I0 \\
\hline 35 & .. & . & 27 & I \\
\hline 36 & .. & . & $\ldots$ & . \\
\hline
\end{tabular}

\begin{tabular}{|c|c|c|c|}
\hline \multicolumn{4}{|c|}{ Average for three traverses } \\
\hline \multicolumn{4}{|c|}{ None } \\
\hline 34 & $\cdots$ & . & . \\
\hline I 58 & $\cdots$ & . & . \\
\hline 339 & . & $\cdots$ & . \\
\hline 462 & $\cdots$ & $\cdots$ & $\cdots$ \\
\hline 668 & $\cdots$ & $\cdots$ & $\cdots$ \\
\hline 722 & . & . & . \\
\hline I9 & . & . & $\cdots$ \\
\hline 4 & $\cdots$ & $\cdots$ & . \\
\hline \multicolumn{4}{|c|}{${ }^{*}$ None ${ }^{\cdots}$} \\
\hline$\ldots$ & 2 & $\ldots$ & . . \\
\hline$\ldots$ & 8 & . & . \\
\hline . & I9 & I & . \\
\hline$\ldots$ & 61 & $\ldots$ & . \\
\hline$\ldots$ & 48 & I & . \\
\hline$\ldots$ & I2 & 2 & . \\
\hline . & 9 & 4 & . \\
\hline . & 6 & I4 & 3 \\
\hline$\ldots$ & I & I2 & * \\
\hline . & . & 26 & 2 \\
\hline . & . & 33 & 3 \\
\hline$\ldots$ & $\ldots$ & 38 & 5 \\
\hline$\cdots$ & $\cdots$ & 34 & 3 \\
\hline$\ldots$ & $\ldots$ & I 2 & I \\
\hline
\end{tabular}


low-water mark of spring tides; sampling beyond low-water mark shows its presence to some depth. Its heaviest concentration is near low-water mark and its abundance is somewhat less than that of $B$. pelagica. The fourth species, $B$. guilliamsoniana, occurs but spasmodically amongst the $B$. elegans, but it becomes abundant and dominant beyond low-water mark.

All the individuals of pelagica, elegans and guilliamsoniana, and a sample of pilosa, from the first traverse, were examined to ascertain the proportion of males to females, and of adult forms to immature forms. Adult maleness

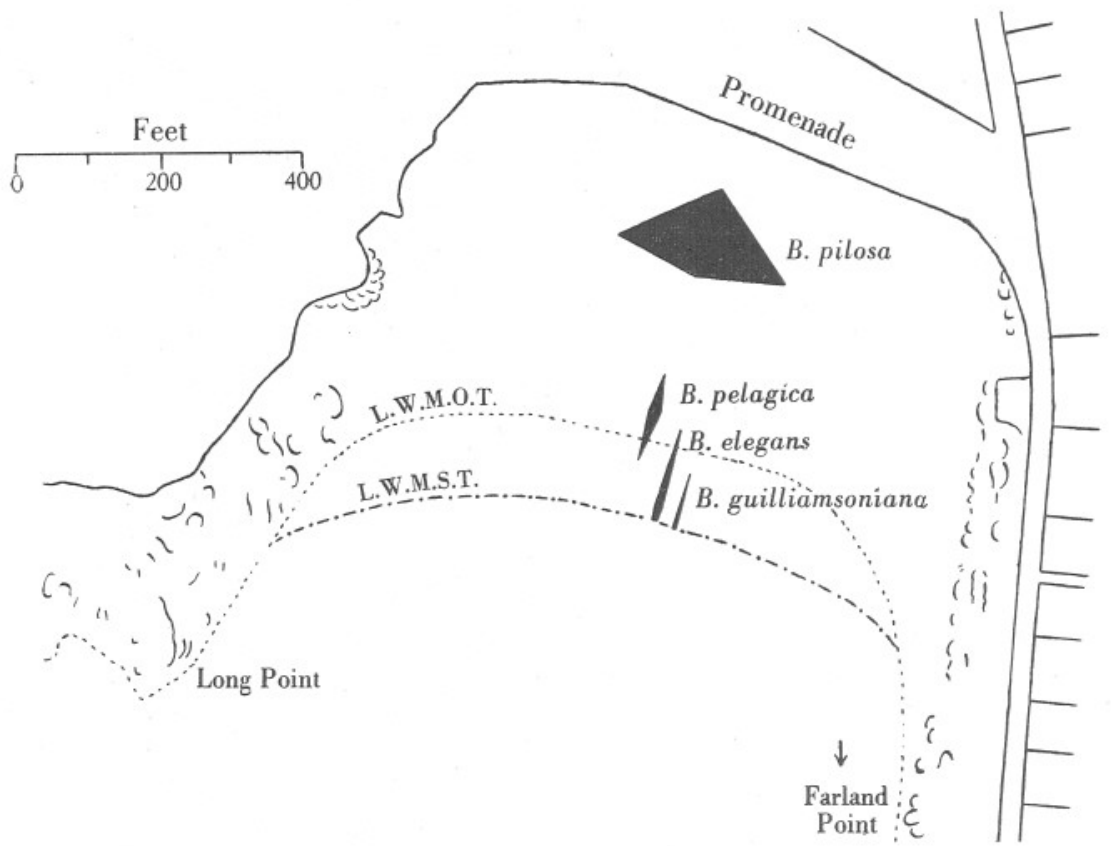

Fig. I. Zonation of Bathyporeia in Kames Bay. Horizontal scale $=\mathrm{ro00}$ individuals to $\mathrm{I}$ in.

was determined by examination of the antenna, adult femaleness by either the presence of eggs in the brood pouch, by setose oostegites, or by the antennae. Individuals are listed as immature if the secondary sexual characters have begun their development, young if the secondary sexual characters are not shown. The result of this analysis is shown in Table II.

Thus, neglecting the differences between the species, the adult male population represents about $15 \%$, the adult female population about $26 \%$, giving a ratio of adults to immature and young forms of $4 \mathrm{I}$ to 59 . It must be borne in mind that the sampling took place in March, when it may be expected that the proportion of adult forms would be at its peak after the almost complete winter cessation of reproduction and before many, if any, of the new season's population are released from the brood pouch. The above figures 
show a small percentage only of young forms; this percentage is probably too low since some young forms, if present, may have escaped through the meshes of the sieve. However, from the point of view of subsequent discussion the main points to be noted are the small percentage of adult males and the much larger percentage of adult females.

Table II. Analysis of the Sex and Age of the Species

\begin{tabular}{|c|c|c|c|c|c|c|}
\hline & $\underset{\hat{0}}{\text { Adult }}$ & 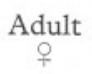 & $\underset{\hat{0}}{\text { Immature }}$ & Immature & $\begin{array}{l}\text { Young } \\
\text { forms }\end{array}$ & Total \\
\hline $\begin{array}{l}\text { B. pilosa } \\
\text { B. pelagica }\end{array}$ & I75 & 260 & 264 & I76 & I4 & 889 \\
\hline B. pelagica & 5 & 32 & 66 & 63 & 56 & 222 \\
\hline $\begin{array}{l}\text { B. elegans } \\
\text { B. guilliamsoniana }\end{array}$ & 13 & 36 & I3 & 43 & 67 & 172 \\
\hline B. guilliamsoniana & 2 & 3 & 3 & I & 2 & II \\
\hline Total & I95 & $33 \mathrm{I}$ & 346 & 283 & I39 & I 294 \\
\hline
\end{tabular}

\section{ANALYsis of THE Tow-NET SAMPLes}

Table III gives the date, time of day when the sample was taken, age of the moon in days, time of high water and species content of forty-six samples taken during the year I936. One sample only, that of September 30, did not contain any Bathyporeia. Thus it may be assumed that some vertical migration into the tidal waters takes place on almost every night of the year. Other samples taken at various times in previous years confirm this view. However, the number per sample is very variable. Of the forty-five samples containing these amphipods twenty gave less than ten individuals, seventeen samples from ten to fifty individuals, four samples from fifty to Ioo individuals, four samples from 100 to 200 individuals and one only over 300 individuals. In view of the high concentration in the sand larger numbers might have been expected in the samples.

The total numbers for each species show a direct relationship to the numbers in the sand with pilosa as the dominant form, with pelagica and elegans in considerably less numbers and with an occasional guilliamsoniana. The individual samples show that, in the main, each species retains its purity when migrating into the tidal waters. Thus thirty-two of the forty-five samples show one species only, eight a mixture of two species, four a mixture of three species, and one only with the four species. It may be expected that pilosa, since it occupies a definite zone on the beach away from the other species, would retain its purity. This is so, in that twenty-two of the samples contain this species only and where it does occur in a mixed species sample its numbers are few. On the other hand, the pelagica and elegans belts overlap to some extent and some admixture of the two species in the tidal waters may be expected. However, here again the samples containing these species are remarkably pure, and where a mixture of more than one species occurs the sample is dominated by one of the species.

It is noteworthy that the species retain their zonation so closely when 
swimming in the tidal waters, which suggests that the time they remain in the water is short. Possibly they make several short excursions from the sand,

Table III. Number of Individuals of each Species Per Sample

A, B. pilosa; B, B. pelagica; C, B. elegans; D, B. guilliamsoniana

\begin{tabular}{|c|c|c|c|c|c|c|c|c|}
\hline Date & $\begin{array}{l}\text { Age of } \\
\text { moon } \\
\text { in days }\end{array}$ & G.M.T. & $\begin{array}{l}\text { Time of } \\
\text { H.W. p.m. } \\
\text { G.M.T. }\end{array}$ & A & B & C & $\mathrm{D}$ & Total \\
\hline 7. i. 36 & I4 & I0.00 p.m. & II $\cdot 44$ & 23 & $\ddot{8}$ & .. & . & 23 \\
\hline I5. i. 36 & 22 & 7.30 p.m. & 4.16 & $\because$ & 8 & . & . & 8 \\
\hline 2I. i. 36 & 28 & I0.30 p.m. & 10.32 & I & .. & .. & .. & I \\
\hline I2. ii. 36 & 20 & 8.30 p.m. & 3.7 & .. & $\ldots$ & I & . & I \\
\hline 13. ii. 36 & $2 \mathrm{I}$ & 7.00 p.m. & $3 \cdot 37$ & .. & 4 & .. & .. & 4 \\
\hline 4. iii. 36 & 12 & II.00 p.m. & 10.38 & $2 \mathrm{I}$ & . & .. & $\cdots$ & $2 \mathrm{I}$ \\
\hline 19. iii. 36 & 27 & 9.00 p.m. & $9 \cdot 34$ & I52 & .. & .. & $\cdots$ & I52 \\
\hline 24. iii. 36 & 2 & 4.30 p.m. & 1.0 & 56 & .. & I & $\ldots$ & 57 \\
\hline 29. iv. 36 & 9 & IO.I5 p.m. & 6.53 & & I6 & 2 & .. & 18 \\
\hline 3o. iv. 36 & 10 & IO.I5 p.m. & 8.10 & II & $\ldots$ & .. & I & 12 \\
\hline I. v. 36 & II & IO.I 5 p.m. & 9.13 & 3 & $\ldots$ & .. & .. & 3 \\
\hline 2. v. 36 & I2 & IO.15 p.m. & 10.2 & 32 & .. & .. & .. & 32 \\
\hline 3. v. 36 & I3 & IO.I5 p.m. & I0.44 & 69 & .. & . & .. & 69 \\
\hline 9.v. 36 & $\begin{array}{l}19 \\
19\end{array}$ & IO.I 5 p.m. & I. 55 & 2 & $\ddot{6}$ & $\ddot{8}$ & I & I7 \\
\hline I4. v. 36 & 24 & I0.15 p.m. & 5.55 & 145 & $\ldots$ & .. & .. & I 45 \\
\hline I5. v. 36 & 25 & IO.I5 p.m. & 7.9 & I & 37 & 2 & $\ldots$ & 40 \\
\hline I6. v. 36 & 26 & IO.I5 p.m. & 8.17 & 4 & 8 & .. & I & I3 \\
\hline I7. v. 36 & 27 & IO.I5 p.m. & 9.19 & 5 & 5 & .. & . & Io \\
\hline 21. v. 36 & $\begin{array}{r}1 \\
2\end{array}$ & IO.I5 p.m. & 0.22 & 24 & .. & .. & . & 24 \\
\hline I. vi. 36 & I3 & I0.15 p.m. & 10.0 & 37 & $\ldots$ & .. & .. & 37 \\
\hline I0. vi. 36 & 22 & II.00 p.m. & 3.49 & 5 & 3 & I & .. & 9 \\
\hline I2. vi. 36 & 24 & $\mathrm{I} 0.30 \mathrm{p.m}$. & 5.32 & & .. & I & $\ldots$ & I \\
\hline I6. vi. 36 & 28 & I0.30 p.m. & 9.52 & 37 & $\ldots$ & .. & .. & 37 \\
\hline 23. vi. 36 & 5 & I.OO a.m. & 3.12 & I 43 & I & .. & $\ldots$ & I 44 \\
\hline 26. vi. 36 & 8 & Ir.oO p.m. & 5.12 & .. & I & 5 & $\ldots$ & 6 \\
\hline 27. vi. 36 & 9 & I.00 a.m. & 5.58 & .. & .. & 7 & $\ldots$ & 7 \\
\hline 2. vii. 36 & I4 & II.OO p.m. & 10.53 & I4 & & 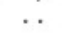 & .. & I4 \\
\hline I4. vii. 36 & 26 & II .00 p.m. & 8.23 & .. & II & .. & . & II \\
\hline 2I. vii. 36 & 4 & II.00 p.m. & 2.9 & .. & 8 & .. & . & 8 \\
\hline 31. vii. 36 & I4 & II.00 p.m. & 10.30 & 370 & .. & .. & . & 370 \\
\hline I2. viii. 36 & 26 & II .00 p.m. & $8.1 \mathrm{I}$ & 2 & $7 \mathrm{I}$ & .. & .. & 73 \\
\hline 2I. viii. 36 & 5 & II.00 p.m. & $2.4 \mathrm{I}$ & .. & 2 & .. & $\ldots$ & 2 \\
\hline 3I. viii. 36 & I5 & II .00 p.m. & II. 35 & I & . & & .. & I \\
\hline 8. ix. 36 & 23 & 9.45 p.m. & 5.II & .. & 4 & $8 \mathrm{I}$ & I & 86 \\
\hline I5. ix. 36 & I & I0.00 p.m. & 0.6 & 32 & & .. & $\ldots$ & 32 \\
\hline 24. ix. 36 & IO & I0.00 p.m. & 5.28 & I & I2 & .. & .. & I3 \\
\hline 3o. ix. 36 & I6 & I0.00 p.m. & II 50 & .. & .. & $\ldots$ & $\ldots$ & \\
\hline $5 \cdot x \cdot 36$ & $2 I$ & I0.30 p.m. & 3.9 & .. & .. & 4 & . & 4 \\
\hline 20. x. 36 & 6 & $\mathrm{I} 0.30 \mathrm{p} . \mathrm{m}$. & $2.4 \mathrm{I}$ & .. & 3 & $\ldots$ & .. & 3 \\
\hline $28 . x \cdot 36$ & I4 & I0.30 p.m. & 10.38 & I & $\ldots$ & .. & .. & I \\
\hline 7. xi. 36 & 24 & 8.30 p.m. & 7.0 & 2 & $\ldots$ & $\ldots$ & .. & 2 \\
\hline I2. xi. 36 & 29 & $\mathrm{I} 0.30 \mathrm{p.m}$ & II. 24 & I & . & $\ldots$ & .. & I \\
\hline 25 xi. 36 & I2 & 8.30 p.m. & 9.14 & 3 & .. & .. & .. & 3 \\
\hline Ir. xii. 36 & 28 & II. $30 \mathrm{p.m}$. & $10.5^{8}$ & 6 & $\ldots$ & $\ldots$ & .. & 6 \\
\hline I4. xii. 36 & 2 & 8.45 p.m. & 0.25 & 26 & .. & $\ldots$ & .. & 26 \\
\hline \multirow{2}{*}{ 22. xii. 36} & IO & 7.30 p.m. & 6.19 & 4 & . & . & $\ldots$ & 4 \\
\hline & & & Total & I 234 & 200 & II 3 & 4 & I55 I \\
\hline
\end{tabular}

which may account to some extent for their scarcity, compared with the numbers in the sand and also their ability to remain within the orbit of their belt in the sand. Their behaviour in a dish in the laboratory, although under 
totally different environmental conditions, confirms this, for an individual will emerge from the sand, swim around the dish for a short time and return to the sand. It cannot be imagined that they perform extensive migrations during the intertidal period and yet return to their particular zone area with the retreating tide. This zonation is further shown when the time of sampling is related to the time of high water. The high-tide samples are composed of pilosa, the mid-tide samples of pelagica, and the low-tide samples of elegans. When the samples are related to whether they were taken on a falling tide or a rising tide little of value emerges. In general the average number per sample is greater when taken on a falling tide. This point requires further investigation.

An analysis of the individuals of each species into their sexual age, for the population obtained by the tow-net, is given in Table IV.

The immediate noticeable feature is the preponderance of adults over immature forms as compared with the numbers shown in Table II for the sand population. The total figures for all species combined give an adult population of over $57 \%$ as compared with $40 \%$. Of the $57 \%$ of adults, $42 \%$ are adult males and $15 \%$ adult females. Thus the dominance of adult males in the tow-net samples is a marked one.

Considering the species individually, of 1234 individuals of pilosa taken in the tow-net samples $57 \%$ are adults (40 \% males and $17 \%$ females), $31 \%$ are immature and $12 \%$ young forms. This dominance of adults is actually much more marked than the actual figures suggest since of the I 48 young forms, I23 were obtained in two samples, those of June 23 and July 3 I. A study of the individual samples shows a considerable variation. An occasional sample like that of March 24 is composed almost entirely of adult males; no sample shows a dominance of adult females. Other samples are composed almost entirely of a mixture of adult males and females, such as that of May I4, whilst others show a high percentage of immature and young forms.

A similar variable population occurs in pelagica with $70 \%$ adult $(60 \%$ male and $10 \%$ female), with I $8 \%$ of immature forms and $12 \%$ of young forms. As in pilosa some samples are almost completely composed of adult males, others with a mixed population of adult males and females, and others with a considerable percentage of young forms.

The figures for elegans show the same general outline as in the above two species with a marked dominance of adult males. Only four individuals of guilliamsoniana were taken and of these three were adult males. 


\section{TABLE IV. Number OF Individuals IN EACH SAMPle at EACH Maturity Stage}

$\mathrm{A}=$ adult males, $\mathrm{B}=$ adult females, $\mathrm{C}=$ immature males with secondary sexual characters developing, $\mathrm{D}=$ immature females with secondary sexual characters developing, $\mathrm{E}=$ young males and females with no secondary sexual characters showing.

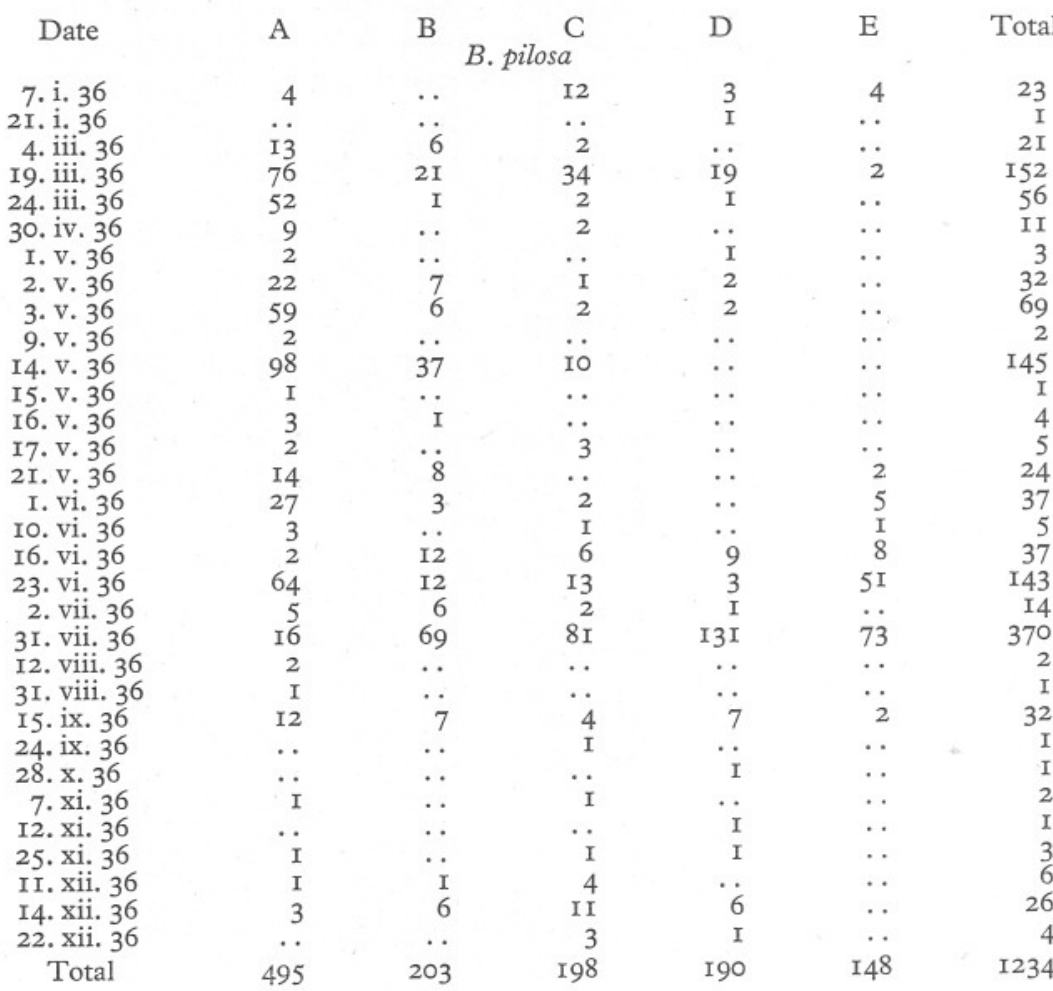

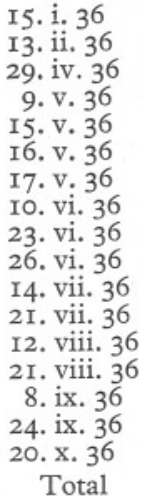

B. pelagica 
TABle IV (CONTINUED).

\begin{tabular}{|c|c|c|c|c|c|}
\hline Date & A & B & & $\mathrm{D}$ & E \\
\hline I2. ii. 36 & I & .. & .. & . & .. \\
\hline 24. iii. 36 & .. & . & I & . & .. \\
\hline 29. iv. 36 & 2 & $\ldots$ & .. & .. & . \\
\hline 9. v. 36 & 8 & .. & .. & .. & .. \\
\hline I5.v. 36 & 2 & . & .. & .. & . \\
\hline IO. vi. 36 & I & .. & .. & .. & .. \\
\hline I2. vi. 36 & I & .. & .. & .. & .. \\
\hline 26. vi. 36 & I & .. & I & . & 3 \\
\hline 27. vi. 36 & 3 & & .. & & 4 \\
\hline 8. ix. 36 & 9 & 18 & 27 & I8 & 9 \\
\hline $5 \cdot x \cdot 36$ & 2 & .. & $\mathrm{I}$ & I & .. \\
\hline Total & 30 & I8 & 30 & I9 & I6 \\
\hline
\end{tabular}

3o. iv. 36

9. v. 36

I6. v. 36

8. ix. 36

Total

\section{B. guilliamsoniana}

$\begin{array}{lllll}. . & . & . & . . & \text { I } \\ . & . & . & . . & \text { I } \\ . . & . & . & . . & \text { I } \\ . & . & \text { I } & . & 4 \\ . . & . . & \text { I } & . . & 4\end{array}$

\section{RELATIONSHIP TO LUNAR MONTH}

The age of the moon in days (with day I as the first day of the new moon) is given in the second column in Table III. If Table IV be rearranged according to the day of the lunar month and all species be considered together irrespective of the season of the year, an indication of the relationship of the occurrence of Bathyporeia with the lunar month can be obtained. These results are represented graphically in Fig. 2.

The result is somewhat uneven, but in general it may be concluded that the number of individuals appearing in the tidal waters increases to two maxima which correspond to the periods immediately preceding full moon and preceding and partly overlapping the appearance of the new moon. The period immediately following the full moon is marked by a distinct scarcity of individuals, although this period is rather inadequately covered by the sampling. A second period of scarcity occurs at the end of the first quarter and beginning of the second quarter. A more detailed study shows that there is no difference in the nature of the population at the two maxima; both are represented by the same proportion of males to females and of adults to young forms. In the figure all four species are grouped together, an attempt to show variability in the behaviour of pilosa, elegans and pelagica gave negative results and detailed figures have consequently been omitted.

\section{Discussion}

The vertical movement of amphipods whose habitat is normally in the soil of the sea floor is a phenomenon which has been recorded by many authors. It is, however, necessary to distinguish between species whose vertical move- 
ments are mainly confined to the hours of daylight and those in which such movement occurs only during the hours of darkness. It is with the latter only that this paper is mainly concerned, and reference to three main papers may be made, Tattersall (1913 $a$ ), Elmhirst (1932), and Fage (1933). Tattersall in his survey of the amphipods of Clare Island and the adjoining district states that "tow-netting in the harbours and shallow waters... at the surface at night has yielded excellent results", and of eighty-four species of gammarid amphipods recorded eleven are given as occurring in plankton samples taken

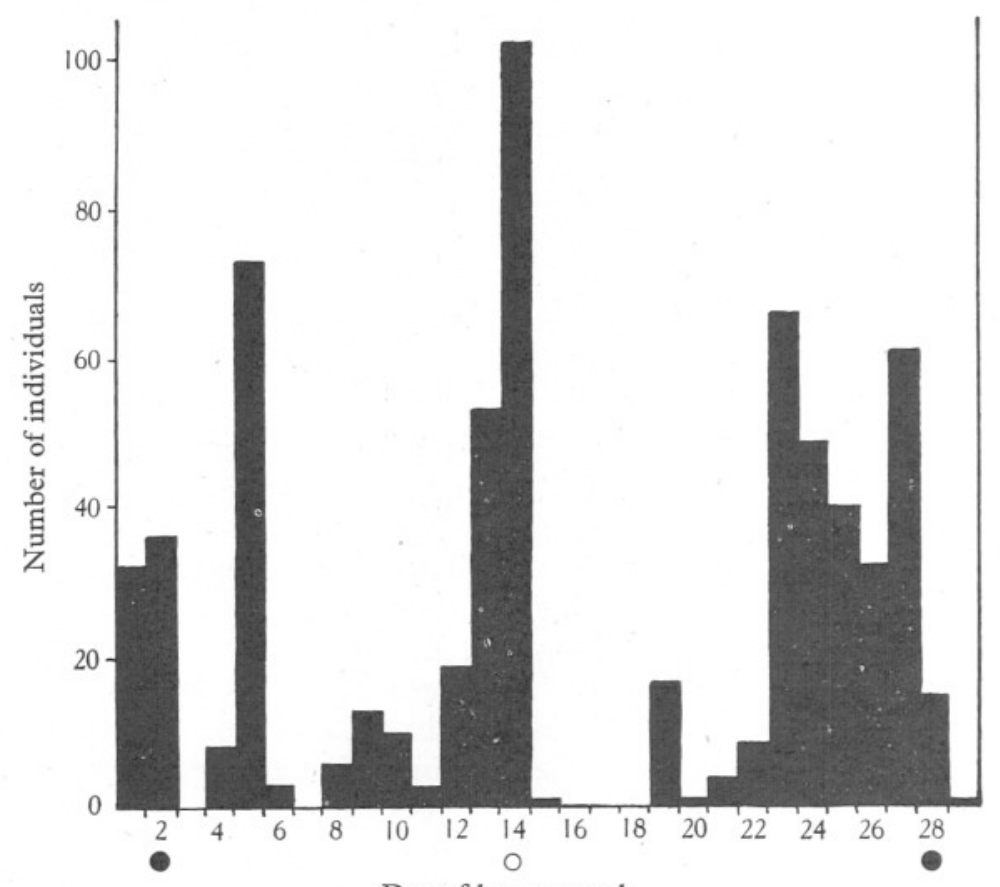

Day of lunar month

Fig. 2. Average number of individuals per day of lunar month.

during the night and twelve as taken in plankton samples during the daytime. Only one species, Guernea coalita (Norman), is recorded as occurring in both the day and night hauls. He gives no details of the sex or age of the specimens captured, but informs me that they were predominantly adult males. Tattersall in another paper $(1913 b)$ shows that many mysids and cumaceans become abundant in the surface waters at night time. Elmhirst records the night tidal migrants of Kames Bay and shows that Gammarus locusta, Bathyporeia sp., Pontocrates sp., Megalopurus agilis, Periculodes longimanus and Paratylus swammerdami are common forms in the night population of the waters of this bay, together with the mysid Schistomysis spiritus and the cumacean Pseudocuma cercaria. Some details of the age and sex are given. Fage in an 
extensive series of samples taken at Banyuls-sur-Mer and at Concarneau at night time, "autour d'un foyer lumineux", records thirty-four species of gammarid amphipods together with several mysids and cumaceans. Comparing the lists of amphipod species as given by Tattersall, Elmhirst and Fage it is interesting to note that seven species are common to the lists of Tattersall and Fage, namely, Metaphoxus pectinatus and fultoni, Synchelidium haplocheles, Perioculodes longimanus, Apherusa bispinosa, Dexamine spinosa and Guernea coalita; five common to the lists of Elmhirst and Fage, namely, Gammarus locusta, Bathyporeia sp., Pontocrates sp., Perioculodes longimanus and Paratylus swammerdami (Nototropis schwammerdami); and but one only common to all three lists, namely, Perioculodes longimanus. Patience (I909) records Metaphoxus pectinatus and fultoni as occurring at night time in the waters of the Firth of Clyde, thus making three species common to all three areas. Several authors refer to the vertical migration of Apherusa bispinosa, Dexamine spinosa and Guernea coalita (see Fage, pp. 2II, 2I8 and 233 respectively). Russell (I925) shows that samples, taken at various depths up to $50 \mathrm{~m}$. in the waters of the English Channel on a moonlight night in July, contain various benthic amphipods belonging to the genera Monoculodes, Bathyporeia and Ampelisca. A species of the genus Urothöe was exceptional in being present in the surface waters at 9 p.m. He further shows (1927) that in a series of samples taken during the day truly benthic amphipods are absent except for species of the genus Apherusa, mainly A. ovalipes and A. clevei. Fish (1925) records, particularly, four species of amphipods in tow-nettings taken at Wood's Hole, Batea secunda, Stenothöe cypris, Monoculodes edwardsi and Calliopus laeviusculus, the two former breeding during the summer, the two latter during the winter, but does not distinguish between day and night migrants. He is doubtful of the extent to which nocturnal vertical migration affects the night population of amphipods in the surface waters. It is interesting to note, however, that of the twenty-six species of benthic gammarid amphipods listed, seventeen belong to families which also show night migrants in the lists of Tattersall and Fage.

Thus it may be stated that it is a feature of certain species of benthic amphipoda, particularly some of those belonging to the families Haustoriidae, Phoxocephalidae, Oedicerotidae, Calliopiidae, Atylidae and Dexaminidae, to perform nocturnal vertical movements. How far such movements are a normal feature of all the species in these families and whether such movement is spasmodic and of rare occurrence in other families, such as certain species in the families Lysianassidae, Ampeliscidae and Gammaridae, must remain a matter of interesting speculation pending much further detailed investigation.

The nocturnal vertical movement of pelagic amphipods, particularly the Hyperiidae, is well known from the work of Hardy \& Gunther (1935) and also Barnard (1932) on the plankton samples of the Discovery Expedition, and the nocturnal vertical movement of macroplankton organisms in general from the work of Russell at Plymouth. It is unnecessary to review this 
literature in this paper since it is probable that such movement of planktonic organisms is of a fundamentally different nature.

A discussion of the factors which control this nocturnal vertical migration must remain largely speculative pending further detailed investigation. That the movement is not a feeding one seems fairly definite, since observations on Bathyporeia, as yet unpublished, show that they feed when lying buried in the sand by projecting sand particles on to the mouthparts and removing the particles of food that cling to the particles. Foxon (1936) also shows that the cumacean Pseudocuma longicorne, which lives in the same habitat, feeds in essentially the same way; in fact it is probable that all benthic littoral amphipods, mysids and cumaceans feed whilst associated with their sea-floor habitat. The association of the movement with the reproductive cycle is suggested by the concentration of adults as compared with young forms. The evidence given above for Bathyporeia, that given by Elmhirst (I932) for other amphipods in Kames Bay, and many of the species referred to by Fage (1933), shows that adults are predominant. The results given by Fage, however, mostly show a much higher percentage of adult males compared with my figures for Bathyporeia. This is probably due to the effect of the lantern in concentrating the adult males with their large eyes and in having a less effect on the adult females with their smaller eyes. Fage (1933), Foxon (1936) and Tattersall (1938) show that similar concentrations of adults as compared with young forms occur also in some mysids and cumaceans. Thus an explanation of this movement may, in part, be found to be associated with the breeding cycle. Foxon's suggestions that "it is unlikely that the formation of pairs would take place in the sand", and that the "function of the swarm is to enable the males and females to locate each other", will apply equally well to Bathyporeia and to the mysids, but it does not explain the presence of numerous immature forms in occasional samples. Tattersall suggests that the vertical movement of immature mysids is probably connected with environmental factors such as temperature, again a suggestion that will apply equally well to Bathyporeia. Fage shows that in certain species such as Gammarus locusta immature forms only are obtained. Thus it is probable that different factors may control the movements of adults and young immature forms. Foxon further suggests in connexion with Pseudocuma longicorne "that where swarms consisting entirely of males are formed, these are forming a swarm into which the females can enter and so find a mate", a suggestion which implies that the males occupy a higher level in the water than the females. This paper supplies no evidence that the males of Bathyporeia occupy a higher level in the water than the females, since the method of capture at the water's edge of the tidal flow does not permit of sampling at various depths, in fact all samples show a mixed population. From further data collected by Mr Elmhirst during 1932 and again during 1936, when samples were obtained at the surface and at a depth of 2 fathoms, it may be concluded that the Bathyporeia population is always a mixed one and no 
swarms consisting entirely of males occur. Fage, however, shows that in four species of the genus Urothöe no female or immature specimen was captured within or without the orbit of the light employed. Thus in certain species a factor which affects adult males only may have to be considered.

Foxon further suggests that "the females come to the surface when eggs are about to hatch so that the young may have the same opportunity of dispersal". Tattersall has made the same suggestion in regard to certain mysids. This suggestion does not account for the presence of adult males and implies that some females with well-developed embryos in the brood pouch would occur. No female with young in the brood pouch was taken throughout this series of samples, the numbers with eggs were relatively few, and the presence of small newly hatched forms in the samples which cannot have escaped through the meshes of the net is not indicated. However, from observations made by Mr A. K. Vaughan of the University College of Wales (as yet unpublished) on the life cycle of Bathyporeia on the Cardiganshire coast, it is known that the release of the young forms from the brood pouch takes place at the periods of new and full moon. Whether this fact bears a relationship to the increase in numbers in the tidal waters in the periods immediately preceding new and full moon must remain at the moment problematical.

The above discussion attempts to find factors controlling the nocturnal vertical movement of Bathyporeia almost entirely in relation to the breeding habits of the species; other factors, however, such as purely physical ones, should be considered. Wheeler (I937), in a discussion concerning the vertical movement of prawns off Bermuda, reaches the tentative conclusion that, of the factors controlling periodicity, light is the most likely one as inhibiting their activity. The evidence on Bathyporeia in this paper shows that periodicity in relation to the lunar cycle is a feature of the vertical movement of the species in this genus. That light is not a major controlling factor in the genus is shown by the fact that the numbers in the tidal waters increase in the periods immediately preceding new and full moon, but that it is a factor seems definitely indicated in that they do not occur in the tidal waters during the day time.

A reference to Table III shows that individuals were taken in all the months of the year with larger numbers in the samples from March to September than in the autumn and winter months. The largest samples were obtained in July, March, May and June in that order, so that temperature cannot be regarded as an important factor apart from the effect which it may have on the breeding cycle.

There remains the possible influence of the tides, which may be regarded as an important factor in an intertidal area. That this factor is of importance is shown by the increase in numbers in the two periods which correspond to the highest rises of the tide in each lunar month. It may be noted that the life cycle of Bathyporeia is such that each batch of eggs takes about 15 days 
to develop, hatch and be released from the brood pouch. In $B$. pilosa broods are produced all the year round, but with larger numbers breeding during the spring and summer months, with an occasional extensive brood during these months, which may account for the larger numbers in the samples at definite periods. It may be noted that $B$. pilosa appears in the samples all the year through. With $B$. pelagica breeding is confined to the spring and summer months, and it appears in the tidal waters apart from an occasional specimen during these months only. The results obtained by Fage (1933) and Fish (1925) show that certain species appear in the plankton for periods of time only, some are summer migrants, others winter migrants. Thus a knowledge of the period and length of the breeding cycle for each species is necessary. Clark (1925) has shown an interesting connexion between the tides and the breeding of the fish Leuresthes tenuis.

It appears that the nocturnal vertical movement of Bathyporeia into the waters of the tidal flow is determined, in part, by the influence of the tides which has some relation to the double breeding cycle in each month.

\section{SUMMARY}

The zonation of four species of the genus Bathyporeia, from high-water mark to low-water mark, in Kames Bay, Millport is given. B. pilosa occurs above the high-water mark of neap tides, $B$. pelagica is a mid-tidal form and $B$. elegans a low-water form. The latter, together with B. guilliamsoniana, extend beyond low-water mark. Of the population, as it occurs in the sand, $15 \%$ are adult males, $26 \%$ adult females, giving a proportion of adult to immature forms of $4 \mathrm{I}: 59$.

The analysis of forty-five tow-net samples taken across the bay at night shows that the same zonation of the species is maintained; the proportion of adults to immature forms in these samples, however, is as $57: 43$, and of the $57 \%$ of adults, $42 \%$ are adult males, $15 \%$ adult females.

When the samples are related to the day of the lunar month it is shown that the numbers increase in the tidal waters in the periods immediately preceding the full moon and preceding and partly overlapping the new moon.

A nocturnal vertical movement appears to be a marked feature of a few benthic amphipod families, but the factors which cause this migration are problematical and require much further investigation.

\section{REFERENCES}

Barnard, K. H., I932. Amphipoda. Discovery Reports, Vol. v, pp. I-326.

ClARK, F. N., I925. The life history of Leuresthes tenuis, an atherine fish with tidecontrolled spawning habits. Cal. Fish and Game Com., Fish Bull., No. ro, pp. I-5 I.

ElmHIRST, R., I932. Quantitative studies between tide marks. Glasgow Naturalist, Vol. x, pp. 56-62.

FAGE, L., I933. Pêches planctoniques à la lumière effectuées à Banyuls-sur-Mer et à Concarneau. III. Crustacés. Arch. Zool. Expér. Gén., Tome 76, pp. I05-248. 
Fish, C. J., I925. Seasonal distribution of the plankton of the Wood's Hole region. Bull. Bur. Fish. Washington, Vol. XLI, pp. 9I-I79.

Foxon, G. E. H., 1936. Notes on the natural history of certain sand-dwelling Cumacea. Ann. Mag. Nat. Hist., Ser. I0, Vol. 17, pp. 377-93.

Hardy, A. C. \& Gunther, E. R., I935. The plankton of the South Georgia whaling grounds and adjacent waters I926-7. Discovery Reports, Vol. XI, pp. I-456.

Patience, A., I909. On the genus Phoxocephalus. Glasgow Naturalist, Vol. I, pp. II6-34.

RUSSELL, F. S., I925. The vertical distribution of marine macroplankton. An observation on diurnal changes. Fourn. Mar. Biol. Assoc., Vol. xIII, pp. 769-809.

1927. The vertical distribution of marine macroplankton. V. The distribution of animals caught in the ring-trawl in the daytime in the Plymouth area. Fourn. Mar. Biol. Assoc., Vol. xiv, pp. 557-608.

Tattersall, W. M., i9iza. Clare Island Survey. Amphipoda. Pt. 42. Proc. Roy. Irish Acad., Vol. xxxi, pp. I-42.

- I913 $b$. Clare Island Survey. Nebaliacea, Cumacea, Schizopoda and Stomatopoda. Pt. 4I. Proc. Roy. Irish Acad., Vol. xxxi, pp. I-IO.

— 1938. The seasonal occurrence of mysids off Plymouth. Fourn. Mar. Biol. Assoc., Vol. xxiII, pp. 43-56.

Watkin, E. E., 1938. A revision of the amphipod genus Bathyporeia. Fourn. Mar. Biol. Assoc., Vol. xxiII, pp. $21 \mathrm{I}-36$.

WheEler, J. F. G., I937. Further observations on lunar periodicity. Fourn. Linn. Soc. London, Vol. XL, pp. 325-345. 